Original Research Paper

\title{
Sedimentology and Ichnology of Late Oligocene Delta Front Reservoir Sandstone Deposit, Greater Ughelli Depobelt, Niger Delta
}

\author{
Raphael Oaikhena Oyanyan and Michael Ndubuisi Oti \\ Department of Geology, University of Port Harcourt, P.M.B. 5323, Port Harcourt, Nigeria
}

Article history

Received: $28-02-2015$

Revised: 05-06-2015

Accepted: 03-07-2015

Corresponding Author: Raphael Oaikhena Oyanyan Department of Geology, University of Port Harcourt, P.M.B. 5323, Port Harcourt, Nigeria

Email: raphoyanyan@yahoo.com

\section{Introduction}

Patterns of sedimentation and erosion in a fluviodeltaic environment are controlled by many factors; among them include sea level changes, tectonic setting and nature of the source area, nature of basin, sediment grain size and climate (Reading, 1986; Coleman and Prior, 1980; Labourdette et al., 2008). Reijers (2011) updated the sedimentological model of the Niger Delta sedimentary basin by Weber (1971) to a model that takes into consideration of the local and delta-wide effects of sea-level cyclicity and delta tectonics. He indicated that sediment deposition was affected by autocyclic and

\begin{abstract}
Sedimentological and ichnological study of cored reservoir sands correlated with wireline $\operatorname{logs}$ between two wells, $0.8 \mathrm{~km}$ distance apart along dip direction, enabled vertical and cross sectional facies variability assessment aimed at determining intra sand-body continuity in longitudinal controlled depositional processes. Ten lithofacies described 62 meters cores of the reservoir sands and seals. Sub-environments of deposition identified with lithofacies associations include proximal delta front-mouth bar, distal delta-front, prodelta-offshore, transgressive marine sandstone and tidal flat. High mica content, poor sorting, very coarse quartz grains, high angle bedding contact, micro-slump folds and absent to sparse bioturbation at the base of an upward-coarsening sequence indicated mouth bar deposition and direct link to a distributary channel. The study of vertical and lateral intrareservoir depositional trends indicated that sediment structural and textural (grain sizes and biogenic features) heterogeneities in the deltaic deposit were controlled by variations in physical energy and mixed interactions of seal level changes, tide, wave, fluvial influx, storm, food supply and oxygen levels. Consequently, there is down-dip lithofacies heterogeneity, pinch out of lithofacies or gradation from coarse grains to finer grains and better sorting. Though ichnodiversity is fairly uniform between the two wells, ichno-abundance and burrow sizes decrease down-dip especially at the proximal delta front-mouth bar deposit. The results of this study improve our knowledge of the characteristics of a mouth bar deposit in a mixed-processes deltaic environment and it can be applied in the characterization of delta front deposit elsewhere with similar depositional processes and tectonic setting.
\end{abstract}

Keywords: Delta-Front, Sub-Environments of Deposition, Lithofacies Heterogeneity, Ichnofacies, Sandbody Continuity, Bioturbation allocyclic processes. Autocyclic cycles result from natural redistribution of energy within a depositional system such as channel meandering or switching and delta avulsion, while allocyclic cycles results from changes in sedimentary system as a result of external causes such as eustatic sea level change, tectonic basin subsidence and climate change. Autocyclic cycles are superimposed on allocyclic cycles. Niger Delta basin is therefore said to be a mixed-processes delta with mixed interaction of sea level changes, tide, wave, fluvial influx and storm. Dynamism in all these factors and processes in the deltaic sediment-transport and depositional system determines the continuity of flow units and flow barriers; 
facies and biogenic textural heterogeneity that have impact on hydrocarbon recovery (Singh et al., 2013; Weber and Van Geuns, 1990; Tyler et al., 1992).

Effective production of hydrocarbon reservoirs requires reliable prediction of facies related reservoir properties and correlation at the inter-well scale. Optimal exploitation of oil and gas assets is more likely when the geologic processes that dictated the characters of sedimentary reservoirs are well understood (Tonkin et al., 2010). Some of the stratigraphic factors that affect production are reservoir continuity and connectivity (Hovadik and Larue, 2007). Therefore, the aim of this study include: (1) to evaluate the vertical and cross sectional or down-dip lithofacies variability and organism responses to the dynamic interplay of rivers, sea level changes, waves, storms and tides; (2) the assessment of intra sand-body continuity/connectivity in longitudinal or down-dip direction; (3) the identification of subenvironments of deposition in a delta-front environment.

\section{Study Area and Geologic Setting}

The study area is located in the Greater Ughelli depobelt of the Niger Delta, a major petroleum producing province with great importance to economy of Nigeria, situated on the West Coast of Africa, between Latitude 3 and $6^{\circ} \mathrm{N}$ and Longitude 5 and $8^{\circ} \mathrm{E}$ (Reijers et al., 1997) (Fig. 1). The study area is approximately $95 \mathrm{~km}$ from
Port Harcourt, Rivers state, Nigeria. It is about 164.16 $\mathrm{km}^{2}$ in size with oil, condensate and gas producing wells. As also shown in the Fig. 1, it is bounded in the north by a major growth fault that has three adjoining antithetic growth faults. Down-dip the major growth faults, are up to eight syndepositional synthetic growth faults with their associated rollover anticline that form fault-dip closure. The two wells, Gabi 55 and 56, used in this study are indicated in Fig. 1 with pink coloured ring. Well Gabi 55 is located at the flank of a rollover anticline to a major synthetic growth fault, while well Gabi 56 is at the crest.

The studied sub-surface sedimentary rocks-D3 reservoir sediments-were recovered from the Agbada Formation- one of the three lithostratigraphic units in the Niger Delta basin (Short and Stauble, 1967). Past studies in Niger Delta indicate that Agbada Formation has a maximum thickness of $4000 \mathrm{~m}$ and characterized by paralic to fluvial-marine sediments organized into coarsening-upward offlap cycles. While the underlying Akata Formation, has maximum thickness of $6500 \mathrm{~m}$ and mainly made up of over pressured marine shale with thin silt and sandy interbeds. The topmost unit is the Benin Formation, which has a maximum thickness of $2000 \mathrm{~m}$ and consists of continental and fluvial sands, gravel and back swamp deposits.

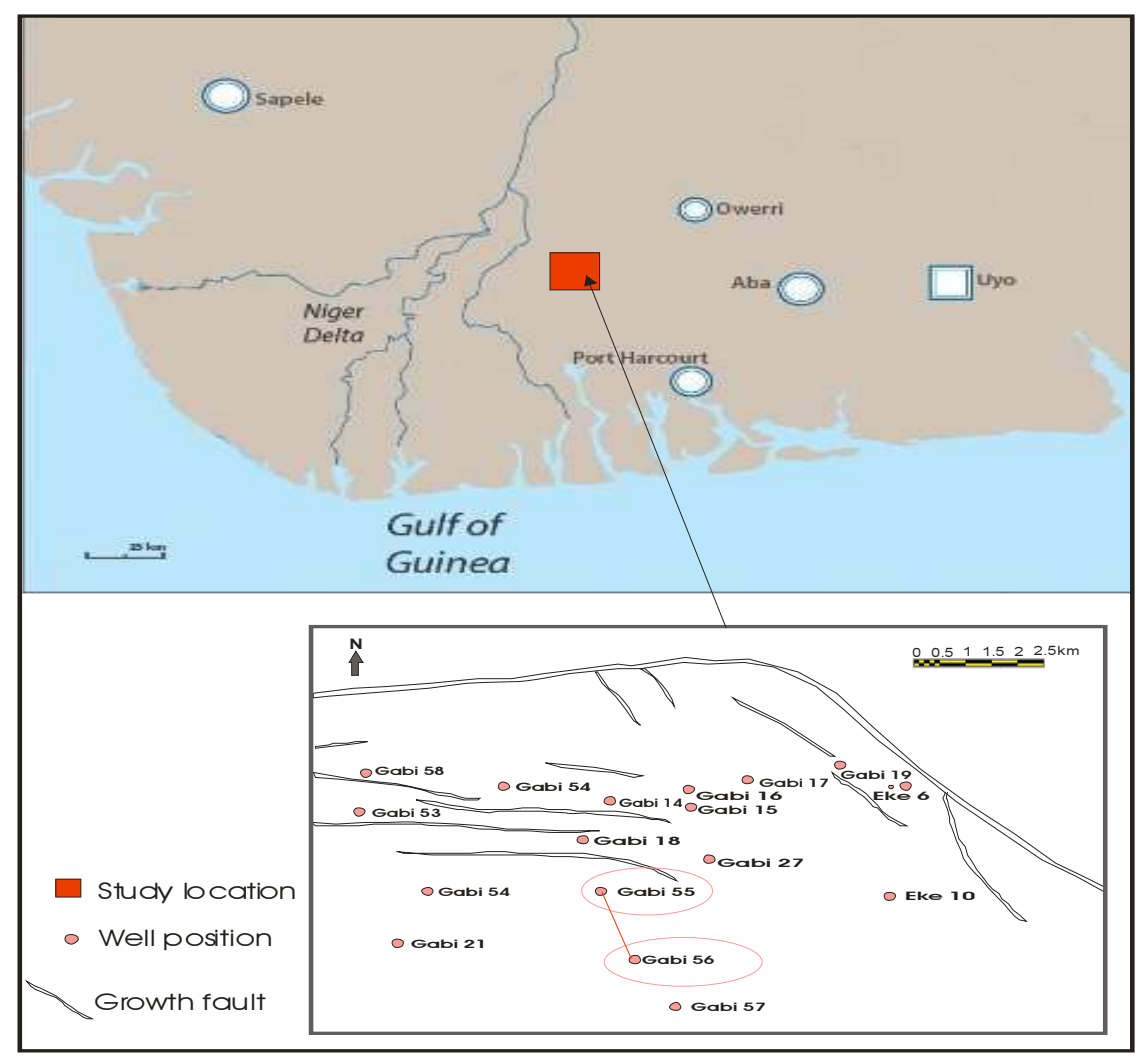

Fig. 1. Location map showing well locations and growth faults. Study oil wells indicated with pink coloured ring 
The aforementioned sediments of Niger Delta basin have been deposited since Palaeocene until present day. The tectonic setting is connected to that of the southern Benue Trough, which is the mega structure it's coastal and oceanward part lies the Niger Delta basin. Benue Trough is a NE-SW folded rift basin that runs diagonally across Nigeria. The tectonic evolution of Benue Trough and Niger Delta are well documented in Niger Delta geologic literatures (e.g., Short and Stauble, 1967; Doust and Omatsola, 1990; Reijers, 2011).

The structural patterns indicate that the delta comprises six depobelts that include the Greater Ughelli where the study area is located. The depobelts are growth fault bounded sedimentary units that succeed each other in a southward direction (Tuttle et al., 1999). Biostratigraphic report of the studied field not discussed here indicates the studied reservoir sediments is Late Oligocene in age and validated the depobelt as Greater Ughelli which according to Reijers (2011) is dominated by wave, fluvial and tide, delta lobe switching and channelization.

\section{Dataset and Method}

Wireline $\log$ s that include gamma ray, resistivity, bulk density and neutron were used to correlate D3 reservoir sands between Gabi 55 and 56 oil wells, 0.8 $\mathrm{km}$ distance apart along dip direction as shown in Fig. 2. A total of 43 and $19 \mathrm{~m}$ cores of D3 reservoir sands and seals from wells Gabi 55 and 56 respectively were examined for lithology, sediment texture (grain size and shape), trace fossils, macro-body fossils, macrodiagenetic features and primary sedimentary structures for the identification of lithofacies and interpretation of environments of deposition. The scheme of Reineck and Singh (1986) was applied in the description and nomenclature of sedimentary structures identified. Trace fossils were recognized using the recognition methods of (Chamberlain, 1978; Pemberton et al., 2009) as well as trace fossils' descriptions in the works of (MacEachern et al., 2005; 2007; Pemberton et al., 2004; Rotnicka, 2005). The degree of bioturbation in cores was classified with bioturbation index of (Taylor and Goldring, 1993; Taylor et al., 2003).

\section{Results}

\section{Sedimentological and Ichnological Analysis}

\section{Lithofacies Analysis}

Ten lithofacies numbered 1 to 10 described D3 cored interval in wells Gabi 55 and 56. The diagnostic features of each lithofacies are indicated in the core photos of Fig. 3 and 4. The lithofacies, their descriptions and interpretations are follows.

Lithofacies 1: Inter-bedded silty shale and finegrained sandstone (Fig. 3a-c). A rock interval made up of dark grey coloured shale with intervals of mm-cm thick siltstone and sharp based ripple laminated sandstone that fines-upward. There are some sideritic nodules in the shale interval. Mix current and wave ripples, flaser and lenticular beddings, abrupt deepening contact and rare truncations within the sand units. It is well-sorted and consolidated with some fractures on the massive shale/silt shale intervals. It is characterised by very low ichnodiversity represented by Planolites burrows and variable bioturbation (BI: 0-3). Bioturbation intensity increases toward the shaley sandstone interval and sharp boundary between sandstone and overlying shale.

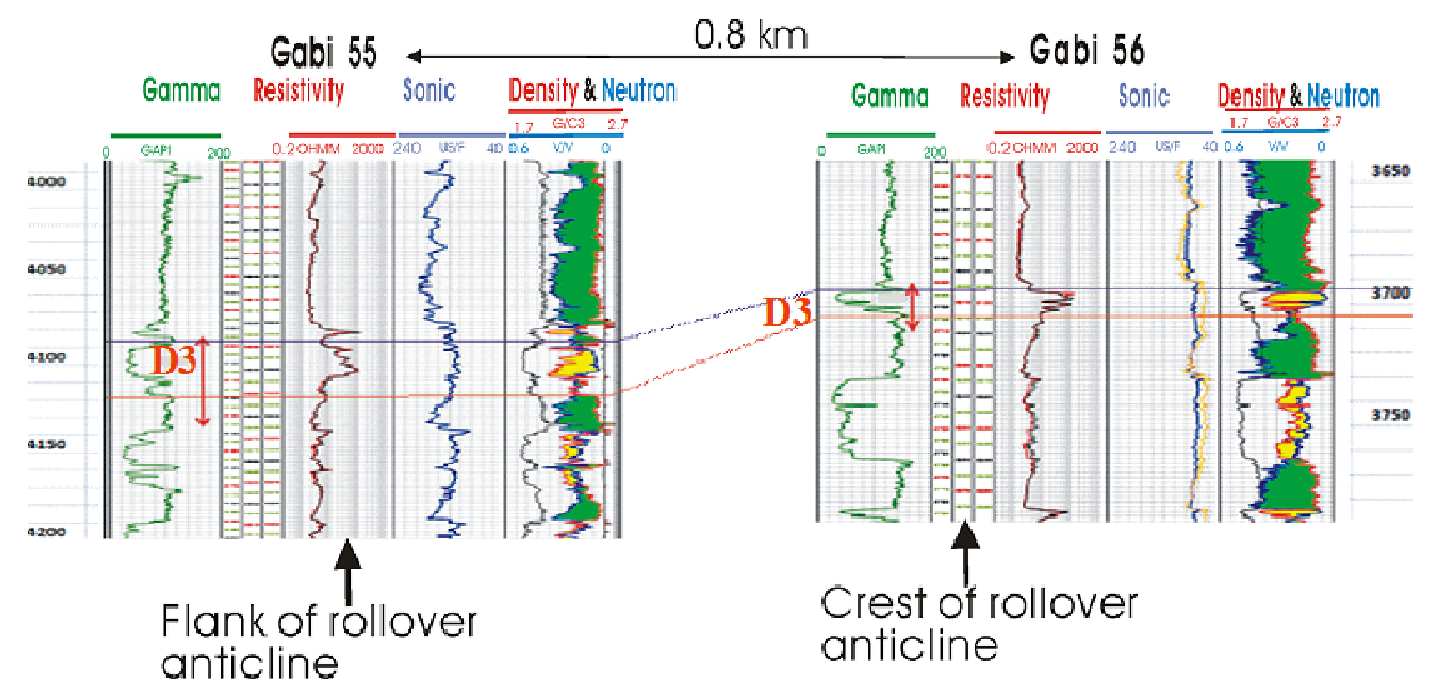

Fig. 2. Log motifs of D3 cored intervals in Gabi 55 and 56 wells 


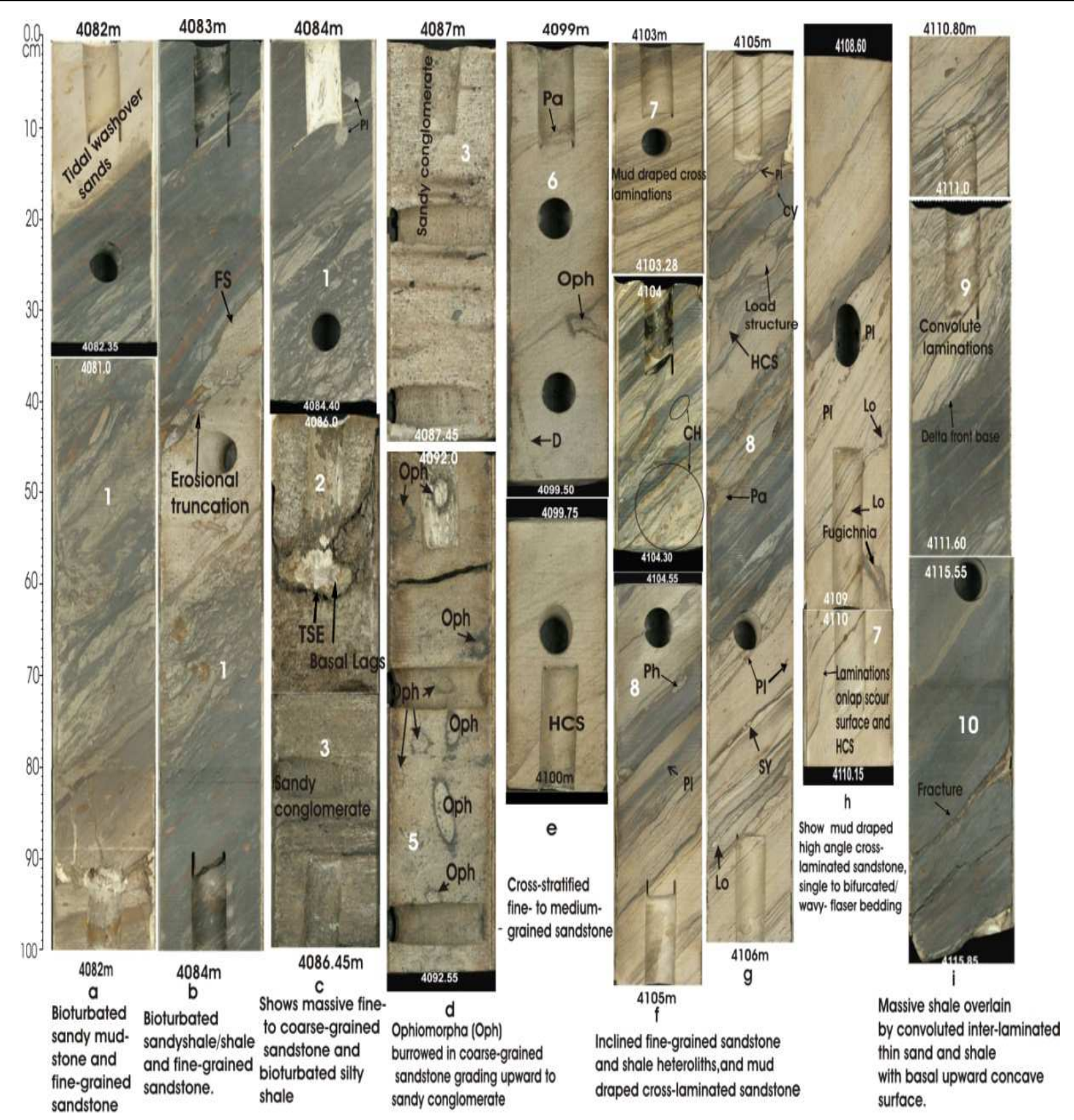

Oph=Ophiomorpha, Ph=Phycosiphon, $\mathrm{Pa}=$ Palaeophycus, $\mathrm{Pl}=$ Planolites, $\mathrm{CH}=$ Chondrites, Lo= Lockeia,

$\mathrm{D}=$ Diplocraterion, $\mathrm{CY}=\mathrm{C}$ Ylindrichnus, $\mathrm{SY}=$ Synaeresis crack, $\mathrm{TSE}=$ Transgressive surface of erosion,

$\mathrm{FS}=$ Flooding surface

Fig. 3(a-i). Core photos showing diagnostic features in lithofacies that described D3 reservoir sands in well Gabi 55

Interpretation. Shale deposit is an indication of suspension settling during slack water condition, while the sand intervals represent periods of higher currents. Sharp based clean sandstone intervals are tidal washover sandstone or sub-tidal deposit in a lagoonal or tidal flat environment. Sideritic nodules indicate reducing condition in deep subaqueous condition. Abrupt deepening, truncations and an increase of bioturbation intensity toward sand-shale contact indicate retrogradational parasequence boundary (Van Wagoner et al., 1990).

Lithofacies 2: Massive coarse-to fine-grained sandstone (Fig. 3c). It is made up of coarse to fine 
quartz grains and massive with faint laminations towards the top. Light grey in colour. It is consolidated, poorly to moderately sorted, micaceous and carbonaceous. It is $0.6 \mathrm{~m}$ thick, fines upward and underlain by an erosive base with basal lags. Interval is unburrowed ( $\mathrm{BI}=0$ ) and characterised by increasing gamma ray log values (Fig. 2).

Interpretation. Structureless and massive deposits indicate quick deposition. The small thickness, poor to moderate sorting and erosive base with basal lags are typical of transgression in shallow marine environment (Weber, 1971). Carbonaceous contents indicate terrestrial influence, while mica flakes indicate constant and high rate of sediment supply to shelf from river (Dias et al., 1984; Selley, 1995).

Lithofacies 3: Gravelly sandstone/sandy conglomerate (Fig. 3d). The rock unit is made up of very coarse quartz grains to granules and pebbles, with lots of mica flakes and some carbonaceous patches. Poorly sorted and well consolidated. Pebbles are sub-rounded to well-rounded. It is greyish brown in colour. It occurs within massive fine-to coarsegrained sandstone and also capping the upward coarsening sequence with funnel log motifs or upward decreasing gamma ray log values. It is massive with no visible primary sedimentary structures but slightly bioturbated with Ophiomorpha burrows $(\mathrm{BI}=1)$. It was only identified in the up-dip well, Gabi 55.

Interpretation. Ophiomorpha burrows are elements of Skolithus ichnofacies associated with high energy environment and also suggest shallow marine depositional setting (Pemberton et al., 2009; MacEachern et al., 2005). Gravelly sandstone with no primary sedimentary indicate quick gravity flow deposition, while sandy conglomerate capping a coarsening upward sequence indicate high energy and wave reworking processes that remove the finer matrix. Typical environment is proximal delta front-mouth bar.

Lithofacies 4: Coarse-to very coarse-grained sandstone (Fig. 4a). It is occasionally pebbly with sharped basal contact and brownish grey in colour. Poorly to moderately sorted and friable to moderately consolidated. It is massive and no visible traces of bioturbation $(\mathrm{BI}=0)$. It occurs at the top of an upward coarsening succession in the down-dip well, Gabi 56. It is suspected that the above described gravelly sandstone/sandy conglomerate in the up-dip well (Gabi 55) grades down-dip to this lithofacies.

Interpretation. Massive and structureless deposit indicates rapid emplacement, with no space of time for bioturbation by benthic organisms (MacEachern et al., 2005). The greyish brown colour indicates subaqueous deposition in an oxygenated shallow water depth such as in proximal delta-front. The very coarse grains and sharp basal contact to mud bed indicate deposition from terminal distributary channel as mouth bars are initiated by bed load deposition and are formed from the coarsest deposits carried by the river (Olariu and Bhattacharya, 2006).

Lithofacie 5: Ophiomorpha burrowed fine-to coarsegrained sandstone (Fig. 3d). It is fine-to coarse quartzgrained sandstone deposit that is micaceous and occasionally granular. Light greyish brown in colour. It is fairly massive with sporadic faint cross-stratification. Moderately to commonly bioturbated by horizontal and vertical/oblique Ophiomorpha burrows $(\mathrm{BI}=3 / 4)$. It was only identified in the up-dip well (Gabi 55).

Interpretation. Abundant Ophiomorpha burrows, suspension feeder structures and elements of Skolithus ichnofacies, reflect sediment deposition in oxygenated, high energy and shallow water depositional setting. Typical depositional environment is upper shoreface or proximal delta front (Pemberton et al., 2009).

Lithofacies 6: Cross-stratified fine-to mediumgrained sandstone. This facies was identified in both updip and down-dip wells. It is upward-cleaning crossstratified fine-to medium-grained sandstone with laminaset thickness ranging from 1.0 to $3.5 \mathrm{~cm}$. It is moderately to well sorted, moderately consolidated and micaceous.

In the up-dip well (Gabi 55), the lithofacies is characterised by rare hummocky lamination, burrows and light brown in colour (Fig. 3e). There are Ophiomorpha burrows on top of the rock unit, while rare Diplocraterion burrows occur at the lower part of the unit, with rare Palaeophycus only at bed boundaries. Bioturbation is generally sporadic ( $\mathrm{BI}=0$ to 2 ). In the down-dip well (Gabi 56), the lithofacies is brownish grey in colour and grades upward from carbonaceous mud draped and sparse to uncommon Ophiomorpha burrowed planar cross-bedded interval to unburrowed trough cross-bedded interval $(\mathrm{BI}=0-3)$ (Fig. $4 \mathrm{a}$ and $\mathrm{b})$.

Interpretation. Planar/trough cross-stratification indicates migration of $2 / 3$ dimension subaqueous dunes, while the mud drapes in the down-dip lithofacies indicate periods of decrease in flow velocity in which mud is deposited on lee slope. The change from brown colour in up-dip well to brownish grey in the down-dip well indicates paleo-seaward increase in water depth. Rare hummocky lamination reflects occasional wave influence. The dominance of Ophiomorpha burrows especially on top of the rock unit is indicative of a stressed environment associated with high energy and high rate of sediment supply. Palaeophycus and Ophiomorpha burrows are elements of Skolithus ichnofacies, while diplocraterion is a common element in the distal end of the Skolithos ichnofacies (Pemberton et al., 2009; Seilacher, 1967). Typical environment of deposition is proximal delta front. 


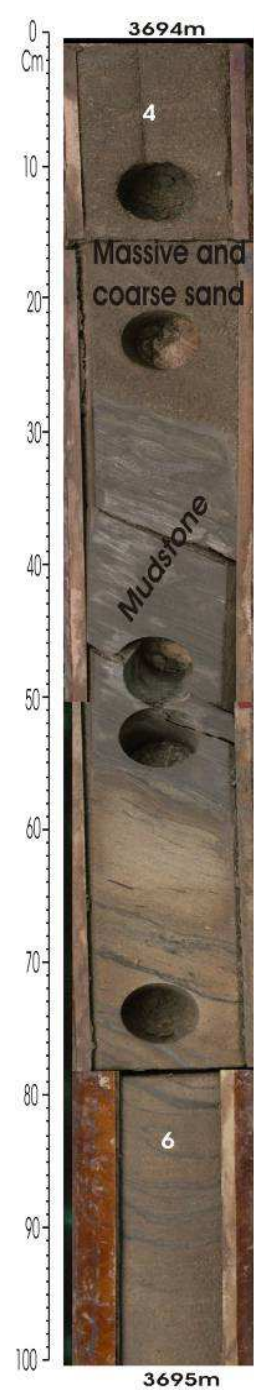

Show mud draped trough sandstone. cross-stratified sandstone, shaly mudstone and massive sandstone

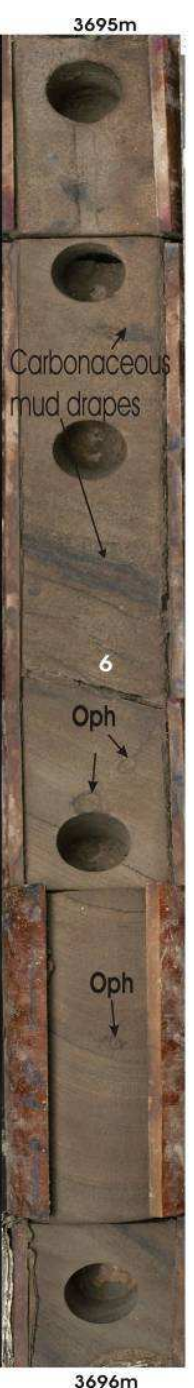

$3698 \mathrm{~m}$
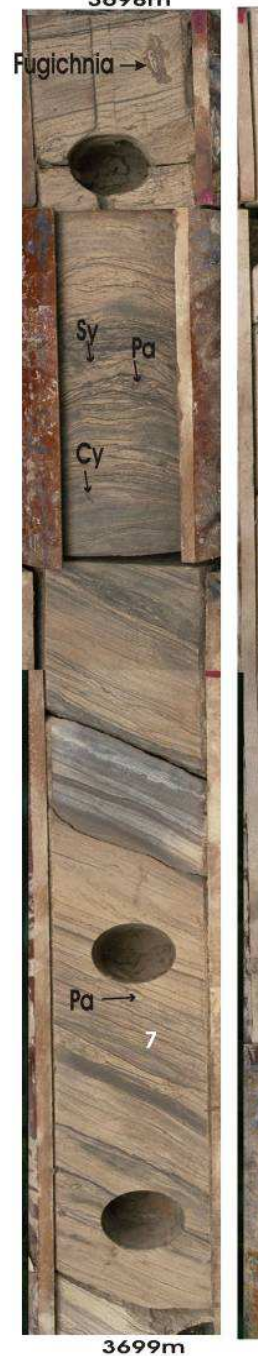

C

Shows mud draped wave Hummocky cross-

rippled (on top) and mud stratified sandston drape current ripple cross-laminations

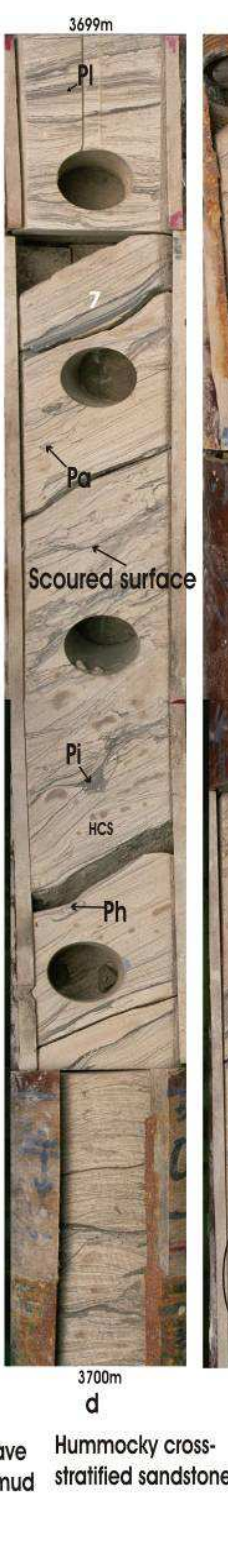

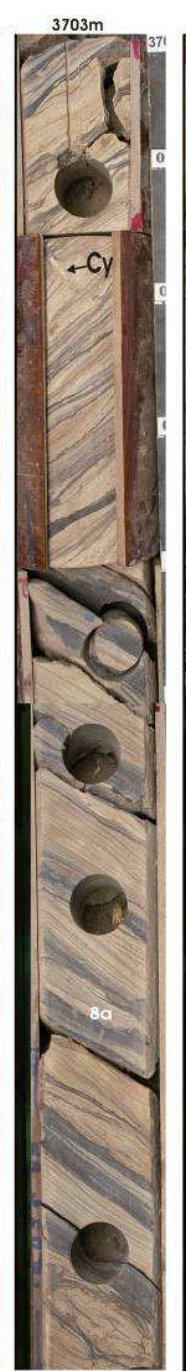

$3704 \mathrm{~m}$

sand dominaied Sand dominaied

Shows ripple paralle

laminated sandstione

bioturbated sandsione, \&
$3704 m$

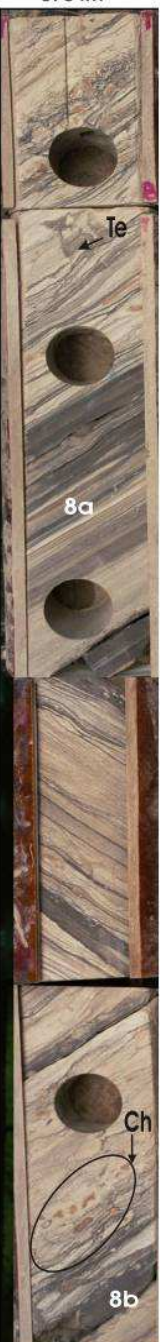

$3705 \mathrm{~m}$

9

Mud dominated Silty shale with intervals of convolute

heterolitihs

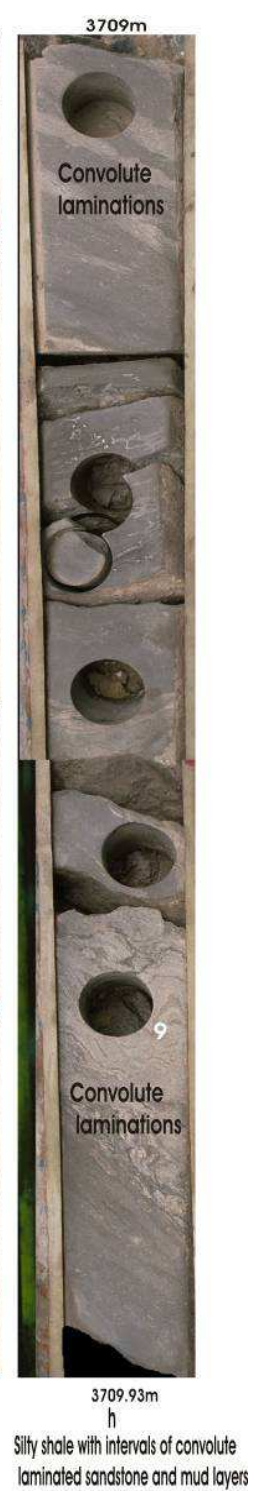

HCS = Hummocky cross stratification, $\mathrm{Clr}=$ climbing ripples, $\mathrm{Pl}=$ Planolites.,Pa= Palaeophycus, $\mathrm{Oph}=$ Ophiomorpha, $\mathrm{CY}=$ Cylindrichnus, $\mathrm{CH}=$ Chondrites, $\mathrm{Pi}=$ Piscichnus, $\mathrm{Sy}=$ Synaeresis crack.

Fig. 4(a-h). Core photos showing diagnostic features of lithofacies that described D3 reservoir sands in well Gabi 56

Lithofacies 7: Mud draped high angle crosslaminated sandstone. This lithofacies was identified both in the updip and down-dip wells. The lithofacies is very fine-grained, well-sorted, consolidated, micaceous and light brown in colour. Sedimentary structures include current ripple cross-laminations, hummocky/wave ripples laminations, climbing ripples, high angle cross-laminations, micro-slumped folds and scoured surfaces. The high angle crosslaminations are draped by single to double mud flasers to occasional 2-4 cm thick shaly mud. Bioturbation is variable $(\mathrm{BI}=0-3)$ and ichnofossils include
Planolites, rare Pischichnus, Fugichnia, Chondrites and rare Phycosiphon and rare Synaeresis crack (Fig. $3 f$ and $h$ ). The thickness of the lithofacies increased in down-dip direction. Distinguishing features of the lithofacies in the down-dip setting are occasional micro-slumped folds, rare Synaeresis crack and diminutive ichnofossils such as Cylindrichnus, Lockeia and Fugichnia (Fig. 4c-e).

Interpretation. Mud draped cross-laminations reflection migration of sinuous crested ripple with mud deposition on the lee slope during periodic drops in depositional current. The mud inter-beds represent fluid 
mud deposit on clinoform surface during waning flow. Rare hummocky cross-lamination indicates occasional influence of storm waves. Periodic waning flow or low energy allows rapid infauna colonisation that result in sporadic bioturbation. Fugichnia, an escape burrow, indicates rapid deposition. Lockeia is an indication of frequent episodic depositional events, while rare Synaeresis crack is an evident of salinity fluctuation due to high sediment influx. Cylindrichnus indicates the proximal end of the Cruziana ichnofacies while Chondrites indicates low oxygen zone (MacEachern et al., 2005; 2007; Pemberton et al., 2009). Typical environment is middle/less distal delta-front.

Lithofacies 8: Inclined fine-grained sandstone and shale heteroliths. It is well-sorted, well consolidated and micaceous. It underlain a coarsening upward sequence and characterised by upward decreasing gamma ray values (Fig. 2). The sand units are characterized by small scale hummocky and swaley cross-laminations, wave ripple laminations or oscillation ripples and rare load structures. Sand and shale thickness are variable (1 to 5 $\mathrm{cm}$ ) but sand shale ratio increases upwards (Fig. $3 \mathrm{f}$ and g). It grades down-dip to two sub-lithofacies in well Gabi 56-sand dominated heteroliths (8a) and mud dominated heteroliths (8b) (Fig. 4e, f and g). The sand dominated heteroliths is dominantly made of sand with shale intercalations that decreases upward in thickness and volume. The mud dominated heterolith that grade upward to sand dominated heterolith consist of 1-10 mm thick massive dark grey shale and 1-2 mm laminated silty shale with intercalated thin very fine-grained sandstone as starved current ripples or lenticular beds. Ichnofossils include Planolites, Chondrites, rare Piscichnus (fish resting burrow), rare Synaeresis crack, Palaeophycus, rare Phycosiphon and Cylindrichnus on the sand-shale boundary. Bioturbation intensity is variable (BI = 0-4,) (Fig. 3f and g; Fig. 4e-g).

Interpretation. High angle bedding implies deposition on an inclined surface. Sand and shale interbeds represent deposit of tidal current of fluctuating strength. The upward decreasing gamma ray values indicate mouth bar or barrier bar deposition (Serra, 1989). Load structure is soft-sediment deformation structure, an evident of rapid deposition. Wave ripple laminations indicate fair weather wave reworking. Hummocky and swaley cross-laminations reflect the influence of storm waves and indicate deposition between storm and fairweather wave base. Rare Phycosiphon and Palaeophycus are bioturbation indices of storm beds (Rotnicka, 2005). Rare Cylindrichnus reflect facies-crossing elements of the proximal end of Cruziana ichnofacies, while Chondrites, though also facies-crossing elements, is an indicative of low oxygen zones (MacEachern et al.,
2005; Pemberton et al., 2009). Typical environment is tide and wave influenced distal delta-front.

Lithofacies 9: Inclined inter-laminated mudstone and siltstone with some lamina or thin layers commonly convoluted. Convolute laminae are similar to (Bouma, 1962) Tc sequence. It has basal contact that is sharp and concave-upward especially at the up-dip well. In the down-dip part, some sandstone intervals are characterised by mud draped wave ripple laminations and soft-sediment folds. It is well consolidated and bioturbation is absent to sparse (BI =0-1) (Fig. 3i and 4h).

Interpretation. High angle inclination and convolute lamination indicate rapid deposition from storm generated hyperpycnal flow on an inclined deposition surface such as seaward margin of a deltaic setting (Coleman and Prior, 1980). The sharp contact represents the asymptotic base of a clinoform or delta front or storm wave base. Sparse bioturbation is characteristic of oxygen-restricted environment. Typical environment is more distal delta front/prodelta.

Lithofacies 10: Grey coloured massive shale, grading upward to lenticular-wavy but rarely contorted siltstone and shale couplets. The lithofacies is rarely fractured and formed the basal part of an upward coarsening sequence. No bioturbation (Fig. 3i).

Interpretation. Massiveness and silt/clay content indicate rapid deposition of suspended load in a low energy environment. The lack of burrows indicates deposition in a deep and anoxic environment. Fractures are an evidence of an overpressure condition (Ingram et al., 1997). Typical environment is offshore or outer shelf.

\section{Sub-Envronments of Deposition}

The characteristics and the associations of the lithofacies described above led to the identification of five depositional facies or sub-environments of deposition. The vertical stacking and distribution of lithofacies in the up-dip and down-dip wells are shown in Fig. 5 and 6 respectively. The sub-environments of deposition are as follows:

\section{Transgressive Sandstone and Tidal Flat Deposit}

A fining upward succession made up of lithofacies 2 (massive coarse- to fine-grained sandstone, underlain by basal lagged erosive surface) grading to lithofacies 1 (inter-bedded silty shale and fine-grained sandstone) is interpreted as transgressive sandstone and tidal flat deposit that records deposition during the transgressive phase of deltaic sedimentation. The carbonaceous and micaceous contents are reflection of deposition in an environment less winnowed by waves and longshore current and also close to distributary channel and mouth bar deposition (Selley, 1995).

Lithofaces 1 interpreted as transgressive tidal flat heterolith, characterized by abrupt deepening surfaces, 
sideritic concretions, flaser and lenticular beddings, truncations, tidal washover sands and bioturbation, indicates open marine tidal flat or lagoon deposit in a retrogradational depositional system (Reineck and Singh, 1986; van Wagoner et al., 1990; Davis Jr and Dalrymple, 2012). While lithofacies 2 interpreted as transgressive sandstone is similar to the Niger Delta transgressive marine sand (onlap sands) described by Weber (1971). Therefore, the facies association records transgressive reworking of the shoreface or mouth bar deposit as it was drown during transgression. Its silty content and stratigraphic position also buttress its proximity to shoreline and active mouth bar deposition. Though this lithofacies association was not cored in the down-dip well (Gabi 56), it was correlated to it with wire line logs. It overlain a coarsening upward sequence and characterised generally by upward increasing gamma ray $\log$ values (Fig. 2 and 5).
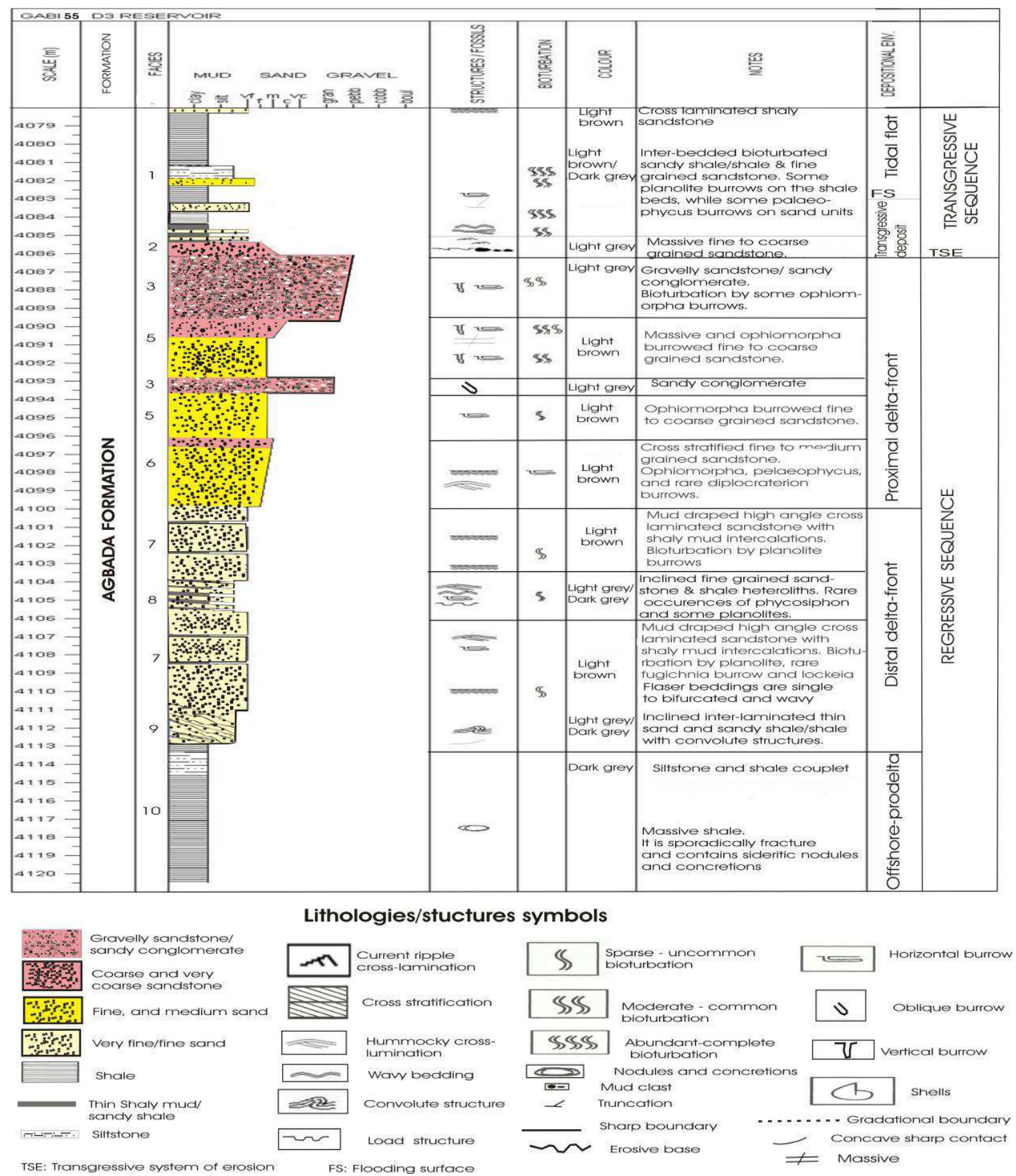

Fig. 5. lithofacies log of D3 reservoir sands in well Gabi 55, showing environments of deposition 


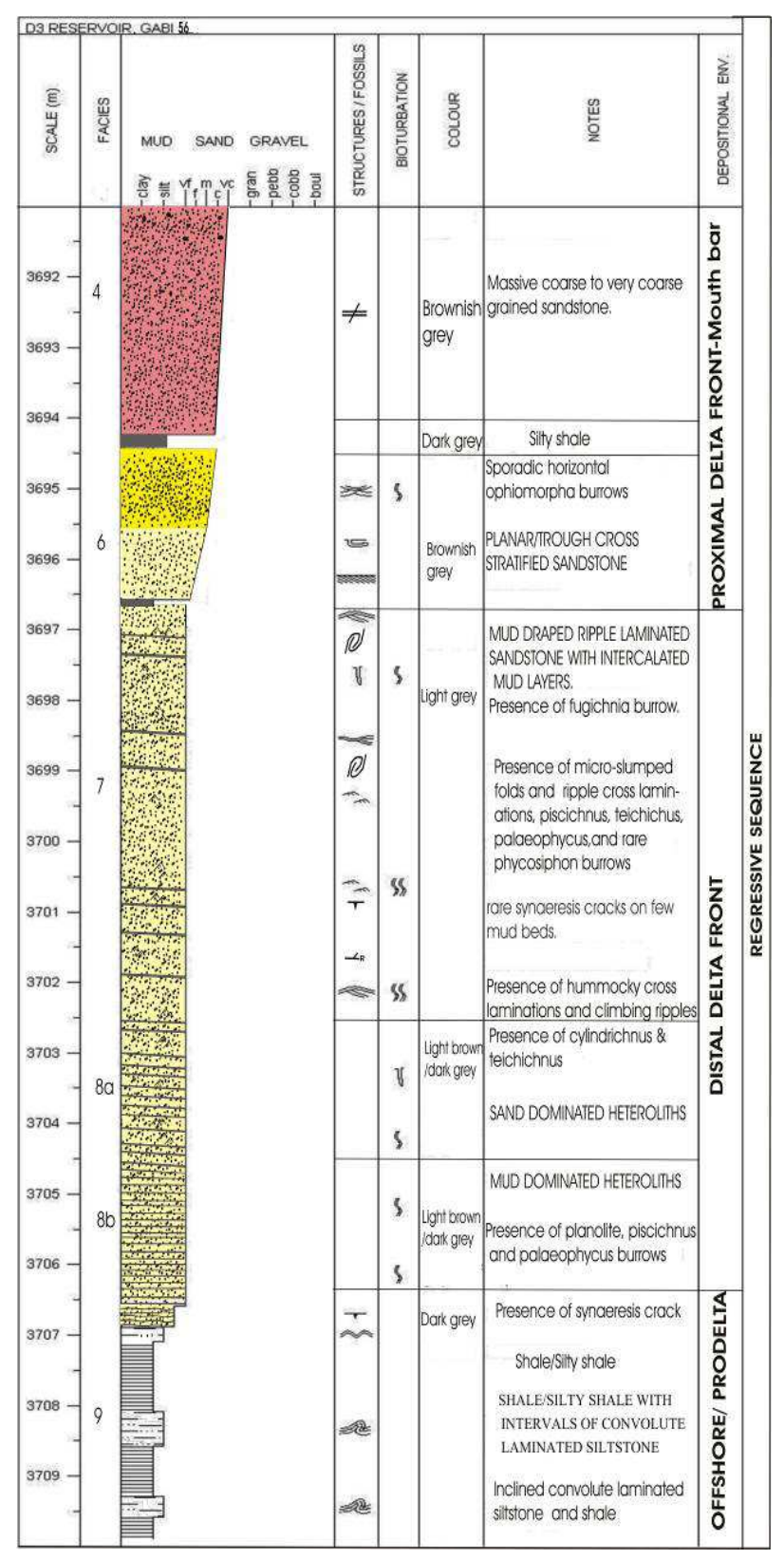

Fig. 6. Lithofacies $\log$ of D3 reservoir sands in well Gabi 56, showing environments of deposition. For legend of sedimentary structures (Fig. 5)

\section{Proximal Delta Front-Mouth Bar}

This lithofacies association is a coarsening upward successions that start with cross stratified fine- to medium-grained sandstone (lithofacies 6) and grades upward through lithofacies 5 and 4 and then to sandy conglomerate (lithofacies 3) (Fig. 5 and 6). It is generally moderately to poorly sorted and has high mica flakes content. It is characterised by abundant Ophiomorpha, rare Palaeophycus and Diplocraterion burrows. It is $17 \mathrm{~m}$ thick and exhibit coarsening upward trend.

Very coarse grain and poor sorted texture and sedimentary structures (massive, cross-bedding and rare hummocky laminations) indicate deposit coeval to a high energy distributary channel. Abundant Ophiomorpha (suspension feeder structures and element of Skolithus ichnofacies), rare Palaeophycus and Diplocraterion burrows reflect deposited sediment in oxygenated, high energy and shallow water depositional setting (MacEachern et al., 2007; Pemberton et al., 2009). The inclination of strata implies delta slope progradation, while, high mica content, very coarse grains and poor sorting indicate a direct link to a distributary channel (Dias et al., 1984; Olariu and Bhattacharya, 2006). These are some of the features that differentiate delta front-mouth bar deposit from that of shoreface. Delta front-mouth bar deposit replaces shoreface where lithofacies characteristics indicate direct link to a distributary channel. Whereas shoreface represents delta front sediments that have been reworked or highly winnowed and re-deposited by wave, tide and longshore current.

\section{Distal Delta Front}

A coarsening-upward successions that grades upward from concave sharp based inclined interlaminated sand and shale with convolute structures (lithofacies 9) through inclined heterolithic finegrained sandstone and silty shale (lithofacies 8) and capped by mud draped high angle cross-laminated sandstone (lithofacies 7) is interpreted as distal delta front or distal-mouth bar facies association (Fig. 5 and 6). It underlain upward-coarsening successions and characterised by upward decreasing gamma ray log values. The top to the mid part of the succession is characterised by high angle cross-laminations, small scale hummocky and swaley cross-laminations, wave ripple laminations or oscillation ripples, rare load structures, flaser bedding and $2-4 \mathrm{~cm}$ mud bed intercalations and sporadic or sparse bioturbation (BI $=1$ to 2) by rare Fugichnia, rare Synaeresis crack, localized sand filled Chondrites, rare Planolites and Palaeophycus burrows and stunted Phycosiphon, Cylindichnus and Lockeia burrows. The base is characterised by convoluted or contorted bedding with sparse to no traces of bioturbation.

Sporadic or sparse bioturbation and stuntedness of some burrows indicate suppressed biogenic activities attributed to the stress in environment caused by fluctuating salinities or temperatures combined with a large suspended-sediment load and rapid deposition (MacEachern et al., 2007). The downward decrease in bioturbation intensity implies downward increase in 
anoxic condition. Loading features resulted from sediment instabilities and density contrasts between rapidly deposited clay, silt and sand. The occurrences of diminutive burrows on sand and mudstone contact and the preponderances of unbioturbated mud beds can best be explained by rapid deposition in distal deltafront. The combination of mudrapes, current ripple laminations and hummocky and swaley crosslaminations is an indication of mixed processes-tide, wave and fluvial-environment and deposition between storm and fair-weather wave base (Walker and Plint, 1992). This is corroborated with rare presence of Phycosiphon and Palaeophycus burrows that are bioturbation indices of storm beds (Rotnicka, 2005). The contorted bedding similar to Bouma (1962) Tc sequence is interpreted as the deposit of hyperpycnal underflows agitated by storm or initiated during highdischarge events (i.e., river floods) at delta-front (Bhattacharya and MacEachern, 2009). According to Coleman and Prior (1980), in delta front environments, mass-movement processes such as small localized slumps often result in distorted laminations. Therefore, they are related to slope instability induced by high sedimentation rates. The sparse bioturbation $(\mathrm{BI}=1-2)$ to no bioturbation $(\mathrm{BI}=0)$ at the base of this lithofacies association clearly differentiates it from the lower shoreface deposit characterised by common to abundant bioturbation (Van Wagoner et al., 1990).

\section{Offshore-Prodelta}

Dark grey coloured massive shale, grading upward to lenticular-wavy but rarely contorted silty sandstone and shale couplets (lithofacies 10) reflecting gradual coarsening-upward succession and underlying the delta front lithofacies successions described above is interpreted to represent offshore-prodelta transitional setting. It is characterised by homogeneous gamma ray $\log$ value (Fig. 2, 5 and 6). It is sparsely bioturbated to unbioturbated $(\mathrm{BI}=0-1)$ and the underlying shale is sporadically fractured and locally sideritic. The locally sideritic massive shale with sparse or no bioturbation structures record deposition in an anoxic environment, below storm wave base, in offshore setting (MacEachern et al., 2005; 2007). The fractures are pore fluid escape structures resulting from high pressure caused by rapid sediment deposition in deltaic environment (Nwozor and Onuorah, 2014).

\section{Discussion}

\section{Down-Dip Correlation of Lithofacies and Ichno- Fossils' Characteristics and Stacking Pattern Development}

Cross sectional facies variability assessment is a method of studying intra sand-body connectivity in longitudinal or down-dip direction. It shows lateral changes in thickness, geometry and lithology-which are components of reservoir heterogeneity. As shown in Fig. 7 , the sub-environments of deposition in which the D3 reservoir sands and seals were deposited and their wireline-log shapes are quite correlatable between the two wells and imply lack of lateral mega or field scale geological heterogeneity, typical of layer cake reservoir architecture (Weber and van Geuns, 1990). However, the foregoing lithofacies analysis of D3 reservoir reveals the following macro/mesoscopic reservoir scale heterogeneities in the depositional dip direction.

\section{Ichnodiversity and Abundance}

Ichnodiversity is fairly uniform between the two wells, but ichno-abundance and burrow sizes decreases from the updip well (Gabi 55) to the down-dip well (Gabi 56) especially at the proximal delta front- mouth bar deposit as indicated by Ophiomorpha burrows. The down-dip decrease in ichno-abundance is attributed to down-dip increase in hydraulic forces associated with wave energy that keep sediment in suspension, thereby increasing the water turbidity that gradually decrease suspension feeding behaviour and also by increase in water depth and traction current due to increase in hydraulic gradient before the basin-ward tectonic uplift by shale diapir as well as down-dip increase in distance from food supply source which is the distributary channel (MacEachern et al., 2005).

The distal delta-front is variably bioturbated in both wells and most burrows typically occurred at sandstone and shale interfaces. The variations in the degree of bioturbation in distal delta-front points to fluctuations in salinity and oxygen levels, sedimentation rates and varying amounts of suspended material in the water column (MacEachern et al., 2005; 2007).

Finally, the ichnoassemblage in the two wells indicates a vertical trend underlain by storm defaunated interval (prodelta), followed by Zoophycus ichnofacies, through Cruziana and mixed Cruziana-Skolithus ichnofacies and then to Skolithus ichnofacies, reflecting vertical increase in physical energy, food and oxygen levels (Seilacher, 1967; Pemberton et al., 2009; Gingras et al., 2007; McIlroy, 2008; MacEachern et al., 2005; 2007; 2012).

The Zoophycus ichnofacies is made up of Chondrites and rare Phycosiphon which are indicative of oxygen limited environment with dysaerobic substrate condition and low deposition (MacEachern et al., 2012). The Cruziana ichnofacies is typified by Cylindrichnus, Palaeophycus, Teichichnus and Fugichnia, while Skolithus ichnofacies is made up of Ophiomorpha and Diplocraterion burrows (MacEachern et al., 2007; 2012; Pemberton et al., 2009; McIlroy, 2008; Pemberton, 1998). 


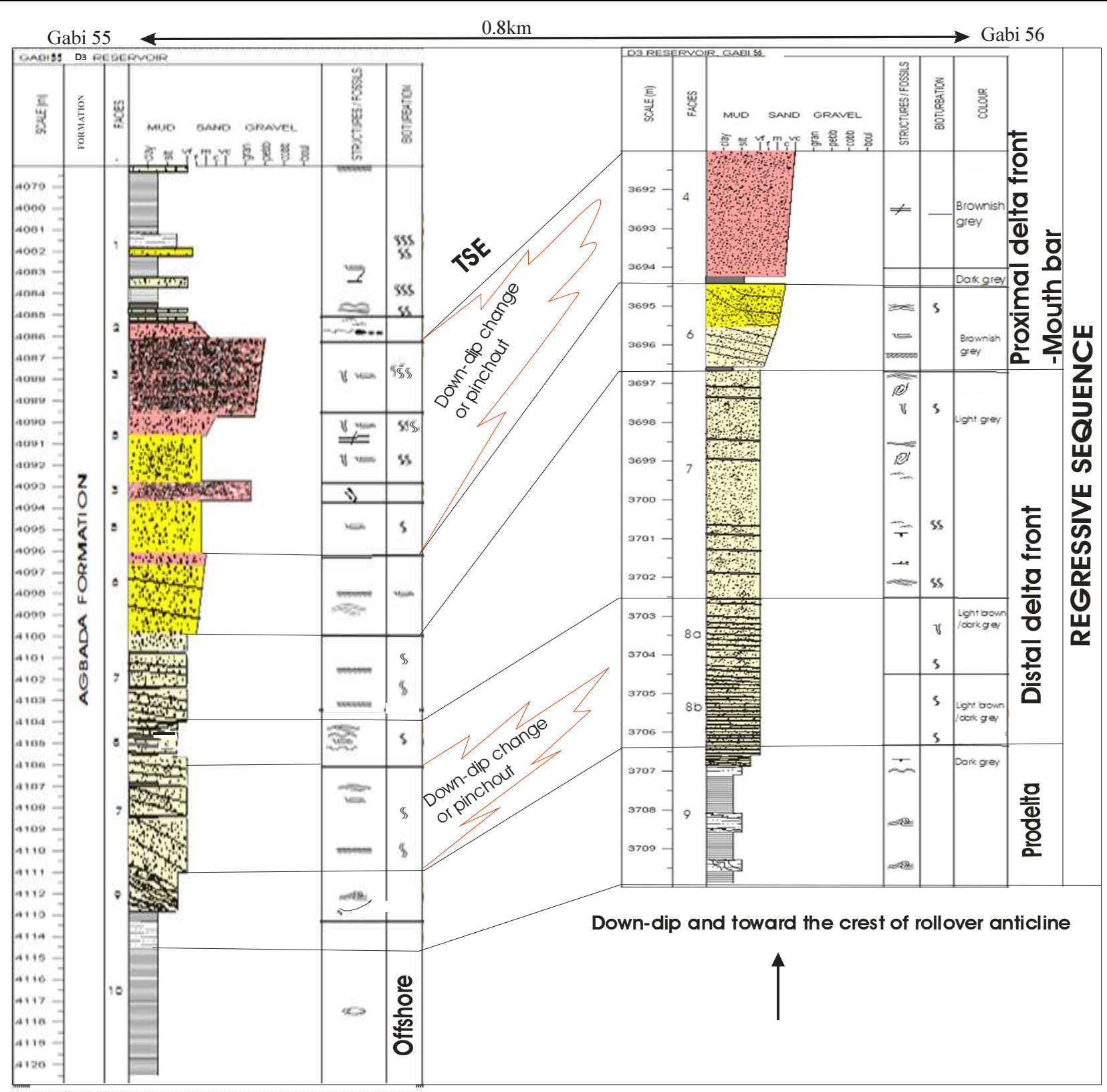

Fig. 7. Down-dip correlations of lithofacies in D3 reservoir. For legend of sedimentary structures (Fig. 5)

\section{Lateral and Vertical Changes in Lithofacies}

The proximal delta-front mouth bar deposit is characterised by down-dip pinch out of some lithofacies or down-dip gradation from coarse texture to finer one. For example, as shown in Fig. 7, gravelly sandstone/sandy conglomerate and ophiomorpha burrowed coarse-grained sandstone in well Gabi 55 grades to massive coarse-grained sandstone in well Gabi 56. The lithofacies changes reflect gradation from bar crest (closed to river mouth) to bar flanks or front deposition where the influence of wave is stronger (Olariu and Bhattacharya, 2006). Also, there is down-dip interfingering of upper facies with the lower one. For example, the baser part of distal delta front facies interfinger or inter-tongue with that of prodelta, while that of proximal delta front also interfinger with that of distal delta front. Therefore, as the proximal delta front reservoir thickness decreases down-dip, that of distal delta front increases (Fig. 7). The distal delta-front, split down-dip into multiple, vertically stacked, upward-coarsening bedsets separated offshore or prodelta mudstones due to paleoseaward deepening of paleobathymetry and increase in tidal energy. 
The cored intervals in the two wells display vertical changes in lithofacies based on variations in grain-sizes, sedimentary structures, bioturbation intensity and ichnofossils. The upward changes in lithofacies reflect increasing sediment supply and stronger fluvial and tide ebb-oriented currents and wave reworking processes higher on the delta-front. High sediment supply and fluvial influence is indicated by high mica content, planar/trough cross-bedding, micro-slumped folds, load structures and rare synaeresis cracks. Wave and storm influence is indicated by the presence of wave ripples, hummocky lamination and contorted bedding and tidal influence is indicated by mud drapes and heterolithic bedding (i.e., centimeter-scale interbedded shale and sandstone). The soft sediment deposition recorded as contorted beds at the lower segment indicates delta progradation to shelf edge and or across the shelf break (i.e., the clinoform rollover or top slope).

\section{Down-Dip Changes in Shalines and Degree of Sorting}

The degree of sorting and shaliness generally increased down-dip. Two mud beds separating upwardcoarsening sandstone bedsets in the proximal/mid delta front, interpreted to represent deposits of intermittent marine flooding, are laterally correlative and relatively continuous; and they have potentials to form flow barriers (Fig. 7). Larue and Legarre (2004) interpreted such laterally continuous shale intervals as minor marine flooding-surface mudstones that vertically compartmentalized reservoirs in an oil field of Western Niger delta. The distal delta-front is heterolithic or made up of interstratified sandstone and shale with shale intervals that increases in thickness in down-dip direction and hence, of greater reservoir heterogeneity and stratigraphic complexities.

\section{Stratigraphic Surfaces and Stacking Pattern Development}

The recognition of Transgressive Surface of Erosion (TSE) and transgressive marine sandstone deposit suggest the presence of a Maximum Flooding Surface (MFS); and the identification of a flooding surface (an abrupt deepening surface) at $4083.4 \mathrm{~m}$ of well Gabi 55 cored interval (Fig. 3c) suggest that the studied reservoir sand body is a progradational parasequence overlain by a retrogradational parasequence set and the characteristics of delta-front deposit described in this study are also similar to the strata characteristics of a deltaic parasequence of Van Wagoner et al. (1990), except with the occurrence of contorted lamina at distal-delta front and concave-upward sharp basal contact that grades down-dip to a gradational contact. The concave-upward sharp basal contact is suspected to be asymptotic lower end of a small-scale clinoform deposit (low angle oblique form), truncating older shelf deposit (Porębski and Steel, 2003). The presence of contorted layers, concaveupward sharp basal contact, variable bioturbation and the absence of an overlying coastal delta plain facies such as a distributary channels and coal bed substantiate deposition close to shelf-margin as consequent of late lowstand relative sea level rise, after the sea level fall that took the shoreline to shelf-margin before the Oligocene regression of Niger Delta basin (Reijers, 2011; van Heijst et al., 2002; Porębski and Steel, 2003; Mellere et al., 2002).

\section{Conclusion}

The deposition of D3 reservoir sands was controlled by variations in physical energy and mixed interaction of seal level changes, tide, wave, fluvial influx and storm, food supply and oxygen levels. The effects of these factors change along deltaic sedimenttransport and depositional route-in the case here, along-dip direction. Consequently, the reservoir sands is characterised by the followings:

- Variability of lithofacies. Ten lithofacies described the cored samples of the D3 reservoir sands and the associations of the lithofacies enabled the identification of sub-environments of deposition that include proximal delta-front mouth bar, distal deltafront, transgressive marine sandstone and open marine tidal flat and offshore-prodelta.

- The degree of sorting and shaliness generally increased down-dip

- Down-dip pinch out of some lithofacies or gradation to lithofacies of finer grains and better sorting

- Though ichnodiversity is fairly uniform from proximal to distal depositional setting, the ichnoabundance and burrow sizes decrease down-dip especially at the proximal delta front-mouth bar

- Sandstone bedsets are separated by $\mathrm{mm}$ to $\mathrm{cm}$ thick mudstone and hence of high potential for vertical subsurface fluid (oil and gas) compartmentalization

- Down-dip correlations of lithofacies between two wells indicate high intra sand-body continuity/connectivity

\section{Acknowledgement}

This paper is part of the $\mathrm{PhD}$ thesis submitted to the Department of Geology, University of Port Harcourt, Nigeria by the first author. The study was ably supervised by the second author. Gratitude is extended to the lecturers and Graduate studies committee of the department for their support. Special thanks to the Department of Petroleum Resources (DPR), Ministry of Petroleum of the Federal Republic 
of Nigeria and Total Exploration and Production Company Limited, Port Harcourt, Nigeria for the provision of the data used for this study.

\section{Author's Contributions}

Raphael Oaikhena Oyanyan: Carried out the $\mathrm{PhD}$ the research from which the paper was written. He wrote the manuscript.

Michael Ndubuisi Oti: Supervised and coordinated the research and read the manuscript.

\section{Ethics}

This article is original and contains unpublished material. The corresponding author confirms that all of the other authors have read and approved the manuscript and no ethical issues involved.

\section{References}

Bhattacharya, J.P. and J.A. MacEachern, 2009. Hyperpycnal rivers and prodeltaic shelves in the cretaceous seaway of north America. J. Sed. Res., 79: 184-209. DOI: 10.2110/jsr.2009.026

Bouma, A.H., 1962. Sedimentology of some Flysch Deposits: A Graphic Approach to Facies Interpretation. 1st Edn., Elsevier, New York, pp: 168.

Chamberlain, C.K., 1978. Recognition of Trace Fossils in Cores. In: Trace Fossils Concepts, Basan, P.B. (Ed.), SEPM Short Course, pp: 119-166.

Coleman, J.M. and D.B. Prior, 1980. Deltaic Sand Bodies: A 1980 Short Course. 1st Edn., Books on Demand, ISBN-10: 0608087297, pp: 175.

Davis Jr, R.A. and R.W. Dalrymple, 2012. Principles of Tidal Sedimentology. 1st Edn., Springer Netherlands, ISBN-10: 978-94-007-0123-6, pp: 621.

Dias, J.M.A., O.H. Pilkey and V.M. Heilweil, 1984. Detrital mica: Environmental significance III north Portugal Continental shelf sediments. Comun. Serv. Geol. Portugal, t. 70: 93-101.

Doust, H. and E.M. Omatsola, 1990. Niger Delta. In: Divergent-Passive Margin Basins. Edwards, J.D. and P.A. Santogrossi (Eds.), American Association of Petroleum Geologists, Tulsa, ISBN-10: 0891813268, pp: 201-238.

Gingras, M.K., L. Bann, J.A. MacEachern and G. Pemberton, 2007. A Conceptual Frame Work for the Application of Trace Fossils. In: Applied Ichnology, MacEachern, J.A., K.L. Bann, M.K. Gingras and S.G. Pemberton (Eds.), SEPM, Tulsa, ISBN-10: 1565761332, pp: 1-26.

Hovadik, J.M. and D.K Larue, 2007. Static characterizations of reservoirs: Refining the concepts of connectivity and continuity. Petroleum Geosci., 13, 195-211. DOI: 10.1144/1354-079305-697
Ingram, G.M., J.L. Urai and M.A. Naylor, 1997. Sealing Processes and Top Seal Assessment. In: Hydrocarbon Seals: Importance for Exploration and Production, Moller-Pedersen, P. and A.G. Koestler (Eds.), Elsevier, Amsterdam, ISBN-10: 0080534287, pp: 165-174.

Labourdette, R., J. Casas and P. Imbert, 2008. 3D Sedimentary modelling of a Miocene deltaic reservoir unit, Sincor field, Venezuela: A new approach. J. Petroleum Geol., 31: 135-152. DOI: $10.1111 / \mathrm{j} .1747-5457.2008 .00412 . \mathrm{x}$

Larue, D.K. and H. Legarre, 2004. Flow units, connectivity and reservoir characterization in a wave-dominated deltaic reservoir: Meren reservoir, Nigeria. AAPG Bull., 88: 303-324.

DOI: $10.1306 / 10100303043$

MacEachern, J.A., K.L. Bann, J.P. Bhattacharya and C.D. Jr, Howell, 2005. Ichnology of Deltas: Organism Responses to the Dynamic Interplay of Rivers, Waves, Storms and Tides. SEPM, pp: 37.

MacEachern, J.A., K.L. Bann, G. Pemberton and M.K. Gingras, 2007. The Ichnofacies Paradigm: HighResolution Pale environmental Interpretation of the Rock Record. In: Applied Ichnology, MacEachern, J.A., K.L. Bann, M.K. Gingras and S.G. Pemberton (Eds.), SEPM, Tulsa, ISBN-10: 1565761332, pp: 27-64.

MacEachern, J.A., K.L. Bann, M.K. Gingras, J.P. Zonneveld and S.E. Dashtgard et al., 2012. The Ichnofacies Paradigm. In: Developments in Sedimentology, Elsevier B.V. (Ed.), pp: 103-138.

McIlroy, D., 2008. Ichnological analysis: The common ground between ichnofacies workers and ichnofabric analysts. Palaeogeography, Palaeoclimatol. Palaeoecol., 270: 332-338.

DOI: $10.1016 /$ j.palaeo.2008.07.016

Mellere, D., P. Plink-Björklund and R.J. Steel, 2002. Anatomy of shelf deltas at the edge of a prograding Eocene shelf margin, Spitsbergen. Sedimentology, 49: 1181-1206.

DOI: $10.1046 /$ j.1365-3091.2002.00484.x

Nwozor, K.K. and L.O. Onuorah, 2014. Geopressure Analysis and Reservoir Fluid Discrimination in a Central Swamp Field, Niger Delta, Nigeria. Petroleum Coal, 56: 124-140.

Olariu, C. and J.P. Bhattacharya, 2006. Terminal Distributary channels and delta front architecture of river-dominated delta systems. J. Sedimentary Res., 76: 212-233. DOI: 10.2110/jsr.2006.026

Pemberton, S.G., 1998. Ichnological dynamics of the Triassic Sag River Fm., Alaska. Report for Arco Alaska, pp: 15. 
Pemberton, S.G., J.A. MacEachern and T.D.A. Saunders, 2004. Stratigraphic Applications of SubstrateSpecific Ichnofacies: Delineating Discontinuities in the Rock Record. In: The Application of Ichnology to Palaeoenvironmental and Stratigraphic Analysis, McIlroy, D. (Ed.), Geological Society of London, London, ISBN-10: 1862391548, pp: 29-62.

Pemberton, G., J. MacEachern, M. Gingras and K. Bann, 2009. Atlas of Trace Fossils. 1st Edn., Elsevier Science, Amsterdam, ISBN-10: 0444532323, pp: 300.

Porębski, S.J. and R.J. Steel, 2003. Shelf margin deltas: their stratigraphic significance and relation to deepwater sands. Earth Sci. Rev., 62: 283-326. DOI: $10.1016 / \mathrm{S} 0012-8252(02) 00161-7$

Reading, H.G., 1986. Sedimentary Environments and Facies. 2nd Edn., Blackwell Scientific, Oxford, ISBN-10: 0632012234, pp: 615.

Reijers, T.J.A., S.W. Petters and C.S. Nwajide, 1997. The Niger Delta Basin: In the African Basin by R.C. Selley, Elsevier Publication, New York, pp: 150-172.

Reijers, T.J.A., 2011. Stratigraphy and sedimentology of the Niger Delta. Geologos, 17: 133-162.

DOI: $10.2478 / \mathrm{v} 10118-011-0008-3$

Reineck, H.E. and B.I. Singh, 1986. Depositional Sedimentary Environment with Reference to Terrigeneous Clastic. 2nd Edn., Singer-Verlag, Berlin, Germany, ISBN-10: 3540101896, pp: 542.

Rotnicka, J., 2005. Ichnofabrics of the Upper Cretaceous fine-grained rocks from the Stolowe Mountains (Sudetes, SW Poland). Geol. Quart., 49: 15-30.

Seilacher, A., 1967. Bathymetry of trace fossils. Mar. Geol., 5: 413-428.

DOI: $10.1016 / 0025-3227(67) 90051-5$

Selley, R.C., 1995. Sub-Surface Environmental Interpretation. In: Ancient Sedimentary Environment and Their Subsurface Diagnostics. Selley, R.C. (Ed.), Routledge,

ISBN-10: 1135075794, pp: 317-317.

Serra, O., 1989. Sedimentary Environments from wire Line Logs Schlumberger Publications. 1st Edn., pp: 243.

Short, K.C. and A.J. Stauble, 1967. Outline of geology of Niger Delta. AAPG Bulletin, 51: 761-779.

Singh, V., I. Yemez and J. Sotomayor, 2013. Key factors affecting 3D Reservoir interpretation and modelling outcomes: Industry perspectives. Brit. J. Applied Sci. Technol., 3: 376-405.

DOI: $10.9734 / \mathrm{BJAST} / 2014 / 3089$
Taylor, AM. and R. Goldring, 1993. Description and analysis of bioturbation and ichnofabric. J. Geological Society, 150: 141-148.

DOI: 10.1144 /gsjgs.150.1.0141

Taylor, A., R. Goldring and S. Gowland, 2003. Analysis and application of ichnofabrics. Earth Sci. Rev., 60: 227-259. DOI: 10.1016/S0012-8252(02)00105-8

Tonkin, N.S., D. McIlroy, D. Meyer and A. MooreTurpin, 2010. Bioturbation influence on reservoir quality: A case study from the Cretaceous Ben Nevis formation, Jeanne d'Arc Basin, offshore Newfoundland, Canada. AAPG Bulletin, 94: 1059-1078. DOI: 10.1306/12090909064

Tuttle, M.L.W., R.R. Charpentier and M.E. Brownfield, 1999. The Niger Delta Petroleum System: Niger Delta Province, Nigeria, Cameroon and Equatorial Guinea, Africa. U.S. Department of the Interior, U.S. Geological Survey, Denver, pp: 130.

Tyler, N., M.D. Barton, D.G. Bebout, R.S. Fisher, J.D. Grigsby and E. Guevara et al., 1992. Characterization of oil and gas heterogeneity: The University of Texas at Austin, Bureau of Economic Geology, topical report prepared for the U.S. Department of Energy, Bartlesville Project Office, DOE/BC/14403-3, pp: 232.

van Heijst, M.W.I.M., G. Postma, W.P.V. Kesteren and R.G. De Jongh, 2002. Control of syndepositional faulting on systems tract evolution across growthfaulted shelf margins: An analog experimental model of the Miocene Imo River field, Nigeria. AAPG Bulletin, 86: 1335-1366.

van Wagoner, J.C., R.M. Jr. Mitchum, K.M. Campion and V.D. Rahmanian, 1990. Siliciclastic Sequence Stratigraphy in Well Logs, Cores and Outcrops: Concepts for High-Resolution Correlation of Time and Facies. 1st Edn., American Association of Petroleum Geologists, Tulsa, ISBN-10: 0891816577, pp: 55.

Walker, R.G. and A.G. Plint, 1992. Wave- and Storm Dominated Shallow Marine Systems. In: Facies Models: Response to Sea Level Change, Walker, R. G. and N.P. James (Eds.), Geological Association of Canada, St., John's, ISBN-10: 0919216498, pp: 219-238.

Weber, K.J., 1971. Sedimentological aspects of oil fields in Niger Delta. Geologie En Mijnbouw, 50: 559-576.

Weber, K.J. and L.C. Van Geuns, 1990. Framework for constructing clastic reservoir simulation models. J. Petroleum Technol., 42: 1248-1297. DOI: $10.2118 / 19582-P A$ 